Journal of Engineering and Applied Sciences 14 (Special Issue 9): 10507-10510, 2019

ISSN: 1816-949X

(C) Medwell Journals, 2019

\title{
Does Wage Influence the Level of Job Satisfaction? Case Study of the Czech Republic
}

\author{
Marcela Sokolova \\ Faculty of Informatics and Management, University of Hradec Kralove, Czech Republic
}

\begin{abstract}
Human resources are one of the most important and the most significant factors that influence the success or failure of a company in a competitive market economy, their job satisfaction is an outstanding condition. The presented study examines how the development of wage amount determines the level of job satisfaction with wages, i.e., the overall level of job satisfaction in the Czech Republic. To determine the level of job satisfaction a questionnaire survey was repeatedly performed-in 2013 and 2015 (1,950 respondents, i.e., 1,547). The dependence between wage development and the level of job satisfaction cannot be unequivocally confirmed because in 2012 there was an annual increase in the average wage of 634 CZK and satisfaction with this determinant was 3.18. Over the next two years there has been an overall increase of 602 CZK (when in 2013 the average wage actually decreased), even then the satisfaction increased toa level of 3.31. This satisfaction can be explained by the fact that after the reduction of the average wage in 2013 there was an increase again. To find dependency it is necessary to create a longer time series, therefore, allowing to examine the long-term satisfaction.
\end{abstract}

Key words: Job satisfaction, determinants of job satisfaction, salary, wage, Czech Republic, decreased

\section{INTRODUCTION}

Human resources are one of the most important and the most significant factors that influence the success or failure of a company in a competitive market economy. They are one of the basic building blocks and without this factor the organization would not achieve good results. The actual personnel management is considered an integral part of the process of governance and management of the entire company.

Only such people who have the expertise, knowledge, skills and abilities have a positive attitude towards work and see opportunities at work for their professional and personal development, bringing success to the organization.

Business owners often underestimate the importance of personnel work in the company, they do not attach much importance to the personal activities and often neglect many of them or do not pay any attention to them at all. It should be noted that for achieving sustained profits it is necessary to develop and grow the business, wherebypeople are an important engine. The businesses whose leadership pays proper attention to personnel work, are characterized by greater loyalty, flexibility and dedication of employees which gives them better results, higher performance and of course profits.

Over the last few decades many studies investigating job satisfaction have been carried out. Theories devoted to job satisfaction as well as tools for evaluating job satisfaction have their origin in Western countries because exploring the issues related to job satisfaction took place mainly in Western Europe and the USA. Due to the globalization of business and the growth of international companies, this area requires a deeper analysis of organizational behavior in different cultures around the world including the Czech Republic.

The first relevant data to examine job satisfaction in the Czech Republic are from 1997 from the International Social Survey Programme (ISSP) which within a single module also focused on job orientation (working conditions, employment characteristics, subjective experience of employment, etc.).

The published studies show (Medgyesi and Robert, 2003; Vecernik, 2003; Franek and Vecera, 2008; Franek et al., 2014) that in the countries of Central and Eastern Europe the level of job satisfaction is relatively low compared with the values of job satisfaction in Western and Northern Europe. The Czech Republic has long been among states with the lowest satisfaction.

Job satisfaction is determined by a set of factors such as the possibility of further career growth and professional development, offers of employee benefits, working conditions, the work itself and a very important component is the pay (Sokolova et al., 2016).

The presented study examines whether the development of the wage amount determines the level of job satisfaction with wages, i.e., the overall level of job satisfaction in the Czech Republic.

\section{MATERIALS AND METHODS}

Research objective and methodology: The subject of this paper is to examine the relation between the amount of pay and job satisfaction with pay, i.e. with overall job satisfaction in the Czech Republic, partial aim of this study is to answer the research question whether the 
development of the amount of pay follows the development of satisfaction with pay, i.e., the overall satisfaction with the work in the Czech Republic.

The limitation of this paper is a short time series tracking job satisfaction (2013 and 2015) but it is possible to track some trends from the partial data.

To determine the level of pay we primarily used the official data from the Czech Statistical Office (Czech Statistical Office-CZSO, 2016). The aim of the data mining in this data is to identify the main development trends in the level of pay in the Czech Republic.

Measuring the level of satisfaction with the work was carried out through a questionnaire survey "Job satisfaction survey” Czech version (Franek et al., 2014; Spector, 1997). This measurement was performed twice-in January and February 2013 and again in the same months during 2015. For the purposes of this study data that describes the level of overall job satisfaction and the determinant of pay will be used.

Data was collected through co-operation with part-time study university students. It used the fact that these students work in different types of organizations in at least three regions of the Czech Republic. After the elimination of incomplete questionnaires the processing included 1,776 respondents, i.e., 1,470 respondents. Statistical analyzes were performed using the statistica 8 software.

Among other things the questionnaire included demographic questions and questions characterizing the organization where the respondent works. The main part of the questionnaire concerned the "Job satisfaction survey” Czech version (Spector, 1997). The questionnaire contained 36 items where respondents had to determine the extent of their compliance with each item on a six-point scale ranging from strongly disagree (Medgyesi and Robert, 2003) to completely agree (Spector, 1997). The resulting data was used to determine the perception of the level of job satisfaction. The overall level of job satisfaction according to the survey methodology is represented by the determinants-the pay, promotion, supervision, fringe benefits, continent rewards, operating conditions, co-workers, nature of the work and communication.

The survey has several limitations for example it concerns the sample group but due to the relatively homogeneous socio-economic composition of the Czech Republic, we can state that the data provide results that expand general knowledge about job satisfaction.

Wage development in the Czech Republic: Labour costs consist of several items. Labour cost structure for 2013 are shown in Fig. 1. In the long term the structure of the labour cost is almost unchanged when in the years 1994-2014, the direct costs range between 70-72\%, the social costs between $25-27 \%$, social benefits between 1-2.5\% (Czech Statistical Office-CZSO, 2016).

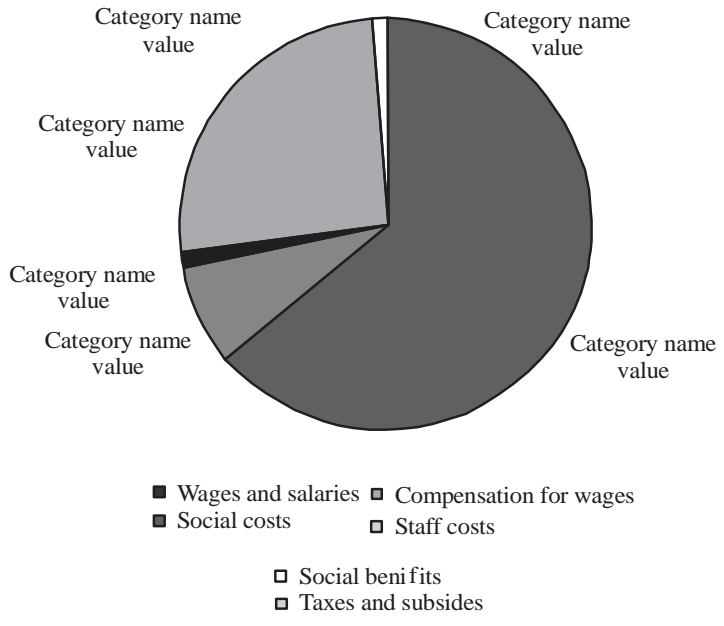

Fig. 1: Structure of labour costs in 2013 (in\%)-selfcreated using the information by Czech Statistical Office-CZSO (2016)

The time series for the period 2009-2014 shows a steady increase in labour costs which is slower in those years. For example in 1994 the average monthly labour costs per employee were 10,244 CZK and in 2004 they amounted to 26,428 CZK and in 2014 amounted to 35,715 CZK. Therefore, during the reporting period the total labour costs increased by almost 3.5 times, the biggest increase occurred in direct costs. The sudden growth was monitoredmainly in 1995 and 1996 (18\% more). Conversely, the lowest growth was in $2009(+0.9 \%)$ and $2010(+2.0 \%)$ in 2013 the wages decreased $(-0.2 \%)$ in comparison with the previous year.

Table 1 shows the trend of development in labour costs by individual components which tracks the average gross monthly wage. According to existing indicators this trend should continue in 2015.

\section{RESULTS AND DISCUSSION}

Study results-the effect of the wages onjob satisfaction in the Czech Republic: The study surveyed 1,776 respondents in 2013 and the repeated survey (2015) 1,470 respondents. The respondents were aged $17-74$ years, i.e., $16-77$ years and their average age was 36.3 years $(\mathrm{SD}=$ $10.80)$, i.e., 36.19 years $(S D=10.70)$. There were approximately 762 men and 1,014 women in 2013 in 2015 it was attended by 619 men and 851 women in both cases they lived mostly in the North-Eastern regions of the Czech Republic. The regions of Hradec Kralove, Pardubice and partly Vysočina (the Czech Republic consists of 14 regions). According to the observed characteristics (gender, age and level of education of the respondents and the characteristics of the organization), it is seen that both surveys are comparable according to the 
Table 1: Monthly labour costs per employee in the Czech Republic (in CZK)

Incl

\begin{tabular}{|c|c|c|c|c|c|c|c|c|c|c|}
\hline \multirow[b]{2}{*}{ Years } & \multirow[b]{2}{*}{$\begin{array}{l}\text { Labour costs, } \\
\text { total }\end{array}$} & \multicolumn{3}{|l|}{ Direct costs (Incl) } & \multirow[b]{2}{*}{$\begin{array}{l}\text { Fringe } \\
\text { benefits }\end{array}$} & \multicolumn{3}{|c|}{ Social costs and expenses (Incl) } & \multirow[b]{2}{*}{$\begin{array}{c}\text { Personnel costs } \\
\text { and expenses }\end{array}$} & \multirow[b]{2}{*}{$\begin{array}{l}\text { Taxes and } \\
\text { subsidies }\end{array}$} \\
\hline & & $\begin{array}{l}\text { Average monthly gross } \\
\text { wage per employee, total }\end{array}$ & $\begin{array}{c}\text { Wages for } \\
\text { work performed }\end{array}$ & $\begin{array}{c}\text { Compensation } \\
\text { for wages }\end{array}$ & & Total & $\begin{array}{c}\text { Statutory social } \\
\text { security }\end{array}$ & Others & & \\
\hline 2009 & 32.611 & 23.425 & 20.909 & 2.516 & 472 & 8.425 & 7.857 & 568 & 356 & -68 \\
\hline 2010 & 33.275 & 23.903 & 21.459 & 2.445 & 467 & 8.633 & 8.216 & 417 & 338 & -67 \\
\hline 2011 & 34.048 & 24.466 & 22.012 & 2.454 & 446 & 8.864 & 8.433 & 431 & 331 & -59 \\
\hline 2012 & 34.786 & 25.100 & 22.538 & 2.562 & 424 & 9.004 & 8.541 & 463 & 317 & -59 \\
\hline 2013 & 34.812 & 25.051 & 22.415 & 2.636 & 424 & 9.087 & 8.603 & 484 & 311 & -62 \\
\hline 2014 & 35.715 & 25.702 & 23.030 & 2.673 & 404 & 9.352 & 8.946 & 406 & 340 & -83 \\
\hline
\end{tabular}

Table 2: The average score for overall job satisfaction and satisfaction with pay (in 2013 and 2015)- self-created

\begin{tabular}{|c|c|c|c|c|}
\hline \multirow[b]{2}{*}{ Items } & \multicolumn{2}{|l|}{2013} & \multicolumn{2}{|c|}{2015} \\
\hline & Pay & Overall satisfaction & Pay & Overall satisfaction \\
\hline \multicolumn{5}{|l|}{ Gender } \\
\hline Males & 3.36 & 3.79 & 3.44 & 3.78 \\
\hline Females & 3.05 & 3.69 & 3.21 & 3.70 \\
\hline \multicolumn{5}{|l|}{ Age } \\
\hline$<30$ & 3.21 & 3.77 & 3.33 & 3.77 \\
\hline $30-40$ & 3.22 & 3.74 & 3.32 & 3.71 \\
\hline $41+$ & 3.12 & 3.68 & 3.27 & 3.71 \\
\hline \multicolumn{5}{|l|}{ Education } \\
\hline Elementary educational level & 3.06 & 3.75 & 2.75 & 3.51 \\
\hline Skilled worker & 3.10 & 3.64 & 2.98 & 3.59 \\
\hline Secondary school & 3.14 & 3.70 & 3.25 & 3.69 \\
\hline Higher professional school & 3.26 & 3.78 & 3.33 & 3.74 \\
\hline Undergraduate (distance learning) & 3.05 & 3.70 & 3.29 & 3.79 \\
\hline University degree education & 3.29 & 3.80 & 3.48 & 3.81 \\
\hline \multicolumn{5}{|l|}{ Years of experience (tenure) } \\
\hline$<5$ years & 3.22 & 3.79 & 3.37 & 3.80 \\
\hline 5-10 years & 3.22 & 3.71 & 3.24 & 3.68 \\
\hline $11-15$ years & 3.06 & 3.61 & 3.19 & 3.64 \\
\hline More than 15 years & 3.11 & 3.70 & 3.35 & 3.73 \\
\hline \multicolumn{5}{|l|}{ Organization ownership } \\
\hline Czech owner & 3.17 & 3.74 & 3.36 & 3.79 \\
\hline Foreign owner & 3.41 & 3.82 & 3.45 & 3.80 \\
\hline International corporation & 3.56 & 3.87 & 3.38 & 3.77 \\
\hline Public/governmental organization & 2.79 & 3.56 & 2.97 & 3.49 \\
\hline \multicolumn{5}{|l|}{ Organization size } \\
\hline up to 50 employees & 3.20 & 3.79 & 3.42 & 3.87 \\
\hline up to 250 employees & 3.08 & 3.68 & 3.20 & 3.63 \\
\hline up to 500 employees & 3.11 & 3.73 & 3.25 & 3.68 \\
\hline more than 500 employees & 3.32 & 3.70 & 3.30 & 3.69 \\
\hline \multicolumn{5}{|l|}{ Job level } \\
\hline Manager/supervisory responsibility employee & 3.53 & 3.91 & 3.60 & 3.85 \\
\hline Non-supervisory responsibility employee & 3.10 & 3.68 & 3.18 & 3.68 \\
\hline
\end{tabular}

examined samples. Table 2 shows the average scores of job satisfaction as well as the average satisfaction score with pay for both surveys (value 1-no. satisfaction; 6-maximum satisfaction).

The overall level of job satisfaction was exactly the samein both surveys, it reached the value of 3.73 but the values of individual determinants influencing the overall satisfaction changed. The determinants of promotion, pay, operating conditions and fringe benefits were identical in both surveys and are among those that reduce the overall level of satisfaction because their value is lower than the overall level of job satisfaction. Conversely, the level of satisfaction with the determinants of supervision, co-workers, nature of the work and communication is higher than the overall level of job satisfaction (whereby the average satisfaction is higher than 4.00).

With the examined determinant of pay the satisfaction of respondents increased from 3.18 in 2013 to
3.31 in 2015. While the satisfaction level of the determinant of pay is the second lowest in both surveys after promotion (2.96, i.e., 3.04), the level of satisfaction increased the most of all of these factors.

Table 2 shows the scores of overall job satisfaction and the determinant of pay for both surveys by selected characteristics of the respondents. Overall satisfaction with work in the Czech Republic has been at very low levels for a very long time which is confirmed by these results.

The level of overall job satisfaction is slightly different in some characteristics of the sample. Men are a little happier than women or Manager/Supervisor responsibility employee than non-supervisory responsibility employee. There are no significant differences between the surveys carried out in the overall job satisfaction in terms of gender, age, work experience and company size. A small difference is seen in the characteristics of education where satisfaction fell 
significantly in people with primary education (but the sample of people is quite small), small increases occurred in people studying colleges. A further reduction in overall work satisfaction occurred with people in multinational companies and the state, contributory and budgetary organizations.

The determinant of pay monitored an increase of satisfaction (from 3.18-3.31) in the surveyed years. The results show that satisfaction with pay increases depending on education and this fact is even more remarkable among the examined years because in people with lower education the job satisfaction reduced and in people with higher education it increased. A significant change can be recorded even with the characteristics of Organization ownership when in Czech owned companiesthere was increase in satisfaction $(+0.19)$ and vice versa in International Corporations the satisfaction decreased (-0.18).

\section{CONCLUSION}

Pay is one of the main determinants affecting job satisfaction. The results show that the overall level of satisfaction with work is reduced by this determinant, even though in the examined years the respondents expressed growth of satisfaction with the factor. Despite some growth in the satisfaction of the pay determinant its level is still very low.

Dependence between the wage development and job satisfaction level cannot be unequivocally confirmed because in 2012 there was an annual increase of the average wage of $634 \mathrm{CZK}$ and satisfaction with this determinant was 3.18. Over the next two years there was an overall increase of 602 CZK (when in 2013 the average wage actually fell), despite that there was an increase in satisfaction to the value of 3.31. This satisfaction can be explained by the fact that after the reduction of the average wage in 2013 there was an increase again. To find the dependency it is necessary to create a longer time series, therefore to examine the satisfaction in long term.

To increase overall satisfaction with work a good trend definitely includes arising wage. On the other hand, it is impossible to prove that wage development follows the trends of satisfaction with pay, i.e., overall job satisfaction. Overall job satisfaction is significantly influenced by other examined determinants and not only them, job satisfaction is affected by e.g., situation in the family or in society in general (political environment, the global financial environment and natural disasters).

\section{ACKNOWLEDGEMENTS}

The study was written with the support of the specific project 6/2016 grant "Determinants affecting job satisfaction” granted by the University of Hradec Králové, Czech Republic.

\section{REFERENCES}

Czech Statistical Office-CZSO, 2016. [The latest data]. Czech Statistical Office, Prague, Czech Republic. (In Czech) https://www.czso.cz/.

Franek, M. and J. Vecera, 2008. Personal characteristics and job satisfaction. E. M. Econ. Manage., 4: 63-76.

Franek, M., H. Mohelska, V. Zubr, P. Bachmann and M. Sokolova, 2014. Organizational and Sociodemographic Determinants of Job Satisfaction in the Czech Republic. Vol. 4, Sage Open, California, USA.,.

Medgyesi, M. and P. Robert, 2003. Satisfaction with work in a European perspective: Center and periphery old and new market economies compared. Rev. Sociology, 9: 43-68.

Sokolova, M., H. Mohelska and V. Zubr, 2016. Pay and offer of benefits as significant determinants of job satisfaction a case study in the Czech Republic. E.M. Econ. Manage., 19: 108-120.

Spector, P.E., 1997. Job Satisfaction: Application, Assessment, Causes and Consequences. Sage Publications, Thousand Oaks, CA., ISBN-13: 978-0761989233, Pages: 104.

Vecernik, J., 2003. Skating on thin ice: A comparison of work values and job satisfaction in CEE and EU countries. Intl. J. Comp. Sociology, 44: 444-471 